\title{
Proceeding
}

Supplementary Issue: Autumn Conferences of Sports Science. Costa Blanca Sports Science Events, 2-3 November 2018.

Alicante, Spain

\section{Practice motivation and life satisfaction of athletes of team sports: Comparative study between adapted and regular sport}

\author{
MARCO BATISTA ${ }^{1} \triangle$, AFONSO LERCAS ${ }^{2}$, JORGE SANTOS ${ }^{1}$, SAMUEL HONÓRIO ${ }^{1}$, JOÃO SERRANO ${ }^{1}$, \\ JOÃO PETRICA ${ }^{1}$
}

${ }^{1}$ SHERU (Sport, Health and Exercise Research Unit), Polytechnic Institute of Castelo Branco, Portugal

2Polytechnic Institute of Castelo Branco, Portugal

\begin{abstract}
Introduction: Sports practice provides not only physical but also psychological and social benefits. Objective: The subject of Adapted Sport is still very scarce and according to that in this study we evaluated and compared Self-Determined Motivation, Basic Psychological Needs, Life Satisfaction and Affects among Athletes of Adapted Sport and Regular Sport, in Handball and Basketball. Methodology: A total of 183 athletes $(N=183)$ participated in which 80 were athletes of adapted sports and the remaining 103 were regular athletes, aged between 16 and 69 . We used four questionnaires that evaluate the variables described: Behavioral Regulation in Sport Questionnaire (BRSQ), Basic Psychological Needs Exercise Scale (BPNES), Life Satisfaction Scale (SWLS) and Positive and Negative Affects Schedule (PANAS). Results: Our results were positive that sports practice has a significant positive effect on life satisfaction in regular athletes, who have more hours of weekly practice than athletes in adapted sports. We have proved the Auto-determination Theory, with the positive correlation obtained in the adapted sport athlete's, between the autonomous motivation and the basic psychological needs, as well as the life satisfaction and the positive affections. We observed that basic psychological needs and positive affects were good predictors of life satisfaction in athletes of adapted sport. In terms of size effect magnitude of adapted sport practice, the number of years of
\end{abstract}

Corresponding author. SHERU (Sport, Health and Exercise Research Unit), Instituto Politécnico de Castelo Branco, Castelo Branco, Portugal. http://orcid.org/0000-0003-3318-2472

E-mail: marco.batista@ipcb.pt

Supplementary Issue: Autumn Conferences of Sports Science. Costa Blanca Sports Science Events, 2-3 November 2018. Alicante, Spain.

JOURNAL OF HUMAN SPORT \& EXERCISE ISSN 1988-5202

(c) Faculty of Education. University of Alicante.

doi:10.14198/jhse.2019.14.Proc1.03

S20 $|2019|$ Proc1| VOLUME 14

C 2019 University of Alicante 
practice showed a reduced to moderate effect in the variables under analysis. Key words: Adapted sport; Self-Determination; Motivation; Basic psychological needs; Subjective Well-Being.

\section{Cite this article as:}

Batista, M., Lercas, A., Santos, J., Honório, S., Serrano, J., \& Petrica, J. (2019). Practice motivation and life satisfaction of athletes of team sports: Comparative study between adapted and regular sport. Journal of Human Sport and Exercise, 14(1proc), S20-S29. doi:https://doi.org/10.14198/ihse.2019.14.Proc1.03 


\section{INTRODUCTION}

This investigation intends to compare two adapted sports (handball and basketball in wheelchair) and two regulars sports (handball and regular basketball), in the psychological determinants, more specifically motivation, basic psychological needs, life satisfaction and affections (positive and negative). Any sport is adapted, it could be adapted to the target audience, to the objectives, to the context, among others. Throughout the work the term "adapted sport" is used to indicate the sports practiced by athletes with disabilities, and the term "regular", to indicate the other sports practiced by so-called "normal" athletes. Motivation is a subject to which researchers have devoted much of their time because of their influence on human behaviour. In the last decades, sport has been growing as a sociocultural phenomenon, so that studies on the technical components, tactics of the game and the physical preparation of athletes have been increasing. However, psychological factors have been forgotten, even though this is a very important factor in athletes' performance and often makes the difference in some decisive moments (Voser, Hernandez, Okubo, \& Junior, 2017). According to Marques (2003), sports psychology has only recently started to be more requested by the clubs and there has been a slow implementation in the last two decades of this scientific area in the training process and the adapted sport is no exception. In general, there are three types of motivation, the intrinsic one that refers to the achievement of activity by personal interest and the pleasurable feelings that come from this same practice (Leal, Miranda \& Carmo, 2013, Ryan \& Deci, 2000a, 2000b; Lepes, Rubio, \& Sheldon, 1997). The extrinsic motivation that is associated to the practice by external factors, that is, behaviours performed according to a specific result, usually these individuals tend to feel more pressured to reach that result/objective, as an example of this motivation are the individuals that practice a sport to achieve social approval and/or physical rewards (Ryan \& Deci, 2000a; Vallerand, 2007, 2001). And the amotivation as the lack or absence of intention to perform certain behaviours, these individuals do not see any purpose for the performance of certain behaviours or activities, do not feel valued, nor pleasure to practice ( Ryan \& Deci, 2000a; Vallerand et al., 1993). The Theory of Self-Determination (TSD) (Ryan and Deci, 2000b) is one of the most well-known theories and considered one of the most important theories of contemporary motivation and used to investigate motivational processes in several contexts in the last decades, being sport and physical activity one of these (Deci et al., 1991). Its central premise is that motivation leads to variations between the amotivation and the intrinsic motivation (Simões \& Alarcão, 2013), with subjects tending to participate more in activities when they regulate their behaviour towards more selfdetermined forms, that is, more intrinsically motivated (Deci \& Ryan, 2002; Pires, Cid, Borrego, Alves, \& Silva, 2010). The TSD refers to the existence of a spectrum or continuum (Figure 1) that encompasses several forms of motivation, ranging from the lowest level (amotivation, external regulation and introjected) to the highest (identified, integrated regulation, and intrinsic motivation, Vallerand et al. (1992) and Vallerand (2007). The TSD is a theory that assumes individuals as active organisms that develop new abilities with growth, solve and surpass the challenges with the involvement given to them, resulting in the integration of new experiences, in coherence with each individual (Deci \& Ryan, 2017). The TSD is a combination of six "mini theories", all developed for the purpose of explaining certain motivational or allusive phenomena that have arisen from the investigation, however we are only going to focus on the Theory of Basic Psychological Needs (TBPN), referring to three requirements for the ideal functioning of the integrative processes of the human being, which are the perception of autonomy, associated with the capacity of the individuals to feel autonomous to initiate a certain behaviour; the perception of competence, concerning the perception of individuals, feel competent in the performance of tasks; and the perception of relationship that has in view a good social relationship with the others. If all of them are satisfied, in the view of the individuals, this will contribute to a greater well-being (Guimarães \& Boruchovitch, 2004; Moreno-Murcia, Marzo, MartinezGalindo, \& Conte Marín, 2011; Ryan \& Deci, 2000b). Subjective well-being consists of two parts, cognitive and emotional. The first is associated with life satisfaction, that is, a global cognitive self-assessment that the 
individual makes at each moment of his life (Santos, 2015), the emotional part is related to the affections these can be positive or negative, individual experiences more positive affects will have higher life satisfaction indices (Diener et al., 2003, Galinha \& Ribeiro, 2005; Siqueira \& Padovam, 2008). The studies in this area of sports psychology are still scarce in the regular sports, so it is not surprising that in the adapted sport are even less. However, the adapted sport that began for rehabilitation benefits, we now know that sports practice can bring improvements in physical, psychological and social aspects, but for people with disabilities, in this case physical, does it have a significantly different effect on regular athletes?

\section{MATERIALS AND METHODOLOGY}

\section{Objective}

This study has as main objectives to evaluate the motivation levels of the athletes of both sports and to compare them with each other, with the basic psychological needs and life satisfaction, as well as to determine if the years of practice have influence on these variables, in the athletes of adapted sport.

\section{Instruments}

In this investigation we used questionnaires as an instrument for quantitative measures, this implies that the answers given by the participants correspond to numerical indices according to the variables of scale under analysis, which result in a set of values. The research consists of four instruments, each one evaluates different variables: the Basic Psychological Needs Exercise Scale (Pires, Cid, Borrego, Alves \& Silva, 2010), Behavioral Regulation in Sport Questionnaire (Londsdale, Hodge \& Rose, And the Positive and Negative Affect Scale (Watson, Clark \& Tellegen, 1988; Watson, Clark \& Tellegen, 1988), the Life Satisfaction Scale (Diener, Emmons, Larsen \& Griffin, 1985; Albuquerque, Sousa \& Simões \& Alarcão, 2013).

\section{Participants}

Thirty-one athletes from four different sports participated in this study, of which 80 are adapted sport athletes and the remaining 103 are regular sports athletes. The age group of regular sport participants is between 16 and 34 , and the adapted sport is between 16 and 69 years. All the participants belong to a national club and are registered in their respective federations.

\section{Procedures}

In order to receive the questionnaires with the most reliable information as possible, all the participants gave their written consent, and before it was fulfilled, we have explained its purpose and contents, explaining all doubts that the participants might had. Subsequently, these were collected and coded to be easier to insert the data in a digital format for analysis.

\section{Statistical Procedures}

We inserted all data in the statistical program Statistical Package for Social Sciences (SPSS 21.0), which allowed us to perform the descriptive and inferential analysis, and we verified the normality requirements from the Kolmogorov Smirnov test and then performed the tests that allowed us the statistical significance levels of $p<0.01$ and $p<0.05$ were considered for a confidence interval of at least $95 \%$.

\section{RESULTS}

We present the results obtained in this investigation, starting with the descriptive statistics, as well as the reliability and normality values of our variables. 
Table 1. Descriptive statistics and reliability analysis of the variables of motivation, basic psychological needs, life satisfaction and positive and negative affects

\begin{tabular}{lcccccc}
\hline Variables & Minimum & Maximum & Mean & $\begin{array}{c}\text { Standard } \\
\text { deviation }\end{array}$ & $\begin{array}{c}\text { Cronbach } \\
\text { Alpha }\end{array}$ & $\begin{array}{c}\text { Kolmogorov } \\
\text { Smirnov }\end{array}$ \\
\hline $\begin{array}{l}\text { Autonomous } \\
\text { motivation }\end{array}$ & 3.00 & 7.00 & 5.80 & 0.85 & 0.89 & 0.174 \\
$\begin{array}{l}\text { Controlled } \\
\text { motivation }\end{array}$ & 1.00 & 5.63 & 1.89 & 0.97 & 0.86 & $0.001^{*}$ \\
$\begin{array}{l}\text { Amotivation } \\
\text { Autonomy }\end{array}$ & 1.00 & 6.50 & 1.92 & 1.18 & 0.88 & $0.001^{*}$ \\
$\begin{array}{l}\text { Competence } \\
\text { Relation }\end{array}$ & 2.00 & 5.00 & 4.05 & 0.64 & 0.76 & $0.013^{*}$ \\
Life satisfaction & 2.25 & 5.00 & 4.18 & 0.56 & 0.78 & $0.010^{*}$ \\
Positive affects & 1.00 & 5.00 & 4.50 & 0.49 & 0.78 & $0.001^{*}$ \\
Negative affects & 1.00 & 7.00 & 5.11 & 1.12 & 0.86 & 0.347 \\
\hline & 5.00 & 3.62 & 0.68 & 0.85 & 0.094 \\
& \multicolumn{7}{c}{${ }^{*} p \leq 0,05$ Does not respect the normality. } & 0.84 & $0.001^{*}$ \\
\hline
\end{tabular}

Table 2 shows the mean values and standard deviations between regular and adapted sport in the different variables under analysis. The two dimensions that obtained higher mean values were Autonomous Motivation and Life Satisfaction in both Sports. In relation to statistically differences, we found them in Controlled Motivation and Life Satisfaction.

Table 2. Means, standard deviations and levels of significance of the dimensions of motivation, basic psychological needs, life satisfaction and positive and negative affects, according to the regular and adapted sport

\begin{tabular}{|c|c|c|c|c|c|}
\hline \multirow[b]{2}{*}{ Variables } & \multicolumn{2}{|c|}{ Regular Sport } & \multicolumn{2}{|c|}{ Adapted Sport } & \multirow[b]{2}{*}{ Sig. } \\
\hline & Mean & $\begin{array}{l}\text { Standard } \\
\text { deviation }\end{array}$ & Mean & $\begin{array}{l}\text { Standard } \\
\text { deviation }\end{array}$ & \\
\hline Autonomous motivation & 5.77 & 0.08 & 5.84 & 0.89 & .62 \\
\hline Controlled motivation & 1.70 & 0.95 & 1.95 & 0.99 & $.04^{*}$ \\
\hline Amotivation & 1.93 & 1.22 & 1.90 & 1.13 & .97 \\
\hline Autonomy & 4.00 & 0.64 & 4.11 & 0.65 & .36 \\
\hline Competence & 4.13 & 0.58 & 4.25 & 0.54 & .13 \\
\hline Relation & 4.49 & 0.51 & 4.51 & 0.48 & .94 \\
\hline Life satisfaction & 5.27 & 0.95 & 4.91 & 1.28 & $.04^{*}$ \\
\hline Positive affects & 3.56 & 0.67 & 3.69 & 0.69 & .18 \\
\hline Negative affects & 1.81 & 0.66 & 1.76 & 0.82 & .15 \\
\hline
\end{tabular}

When performed the one-way ANOVA and Kruskal-Wallis variance tests, we found statistically significant differences in the variable of Life Satisfaction, for male gender and in the relation perception variable for female gender (Table 3).

We performed a linear regression test to verify if the satisfaction of Basic Psychological Needs (independent variable or predictor) predicts good levels of Life Satisfaction (dependent variable), represented by the symbol $R^{2}$. We grouped the variables into three groups (Motivation, Basic Psychological Needs and Affects), and the 
affection group explains $30 \%$ of life satisfaction in Adapted Sport athletes (table 4).

Table 3. Level of significance of the comparisons between Regular Athletes for the variables of Motivation, Basic Psychological Needs, Positive and Negative Affects, according to gender

\begin{tabular}{|c|c|c|c|c|c|c|}
\hline \multirow[b]{2}{*}{ Variables } & \multicolumn{2}{|c|}{ Male } & \multirow[b]{2}{*}{ Sig. } & \multicolumn{2}{|c|}{ Female } & \multirow[b]{2}{*}{ Sig. } \\
\hline & $\begin{array}{c}\text { Regular } \\
\text { sport }\end{array}$ & $\begin{array}{c}\text { Adapted } \\
\text { sport }\end{array}$ & & $\begin{array}{c}\text { Regular } \\
\text { sport }\end{array}$ & $\begin{array}{c}\text { Adapted } \\
\text { sport }\end{array}$ & \\
\hline $\begin{array}{l}\text { Autonomous } \\
\text { motivation }\end{array}$ & $5.78 \pm 0.84$ & $5.88 \pm 0.89$ & 0.48 & $5.75 \pm 0.77$ & $5.25 \pm 0.73$ & 0.20 \\
\hline Controlled motivation & $1.78 \pm 1.01$ & $1.99 \pm 1.00$ & 0.10 & $1.39 \pm 0.59$ & $1.52 \pm 0.70$ & 0.84 \\
\hline Amotivation & $1.98 \pm 1.29$ & $1.94 \pm 1.15$ & 0.90 & $1.74 \pm 0.99$ & $1.42 \pm 0.66$ & 0.43 \\
\hline Autonomy & $4.04 \pm 0.63$ & $4.11 \pm 0.66$ & 0.52 & $3.85 \pm 0.65$ & $4.00 \pm 0.52$ & 0.94 \\
\hline Competence & $4.18 \pm 0.57$ & $4.26 \pm 0.54$ & 0.28 & $3.95 \pm 0.62$ & $4.13 \pm 0.44$ & 0.81 \\
\hline Relation & $4.54 \pm 0.50$ & $4.56 \pm 0.45$ & 0.89 & $4.33 \pm 0.53$ & $3.88 \pm 0.31$ & $0.03^{*}$ \\
\hline Life satisfaction & $5.37 \pm 0.93$ & $4.92 \pm 1.31$ & $0.02^{*}$ & $4.90 \pm 0.92$ & $4.80 \pm 0.86$ & 0.81 \\
\hline Positive affects & $3.62 \pm 0.64$ & $3.70 \pm 0.71$ & 0.51 & $3.32 \pm 0.72$ & $3.67 \pm 0.52$ & 0.28 \\
\hline Negative affects & $1.78 \pm 0.69$ & $1.70 \pm 0.77$ & 0.13 & $1.89 \pm 0.57$ & $2.48 \pm 1.16$ & 0.26 \\
\hline
\end{tabular}

Table 4. Linear regression for the variables of Motivation, Basic Psychological Needs, Life Satisfaction, Positive Affects and Negative Affects for Adapted Sport

\begin{tabular}{cccccc}
\hline & & & \multicolumn{3}{c}{ Life satisfaction } \\
\hline & Variables & Beta & $\mathbf{t}$ & $\boldsymbol{p}$ & $\mathbf{R}^{\mathbf{2}}$ \\
\hline \multirow{3}{*}{ Group 1 - Motivation } & Autonomous motivation & 0.15 & 1.35 & 0.18 & \\
& Controlled motivation & -0.01 & -0.09 & 0.93 & 0.07 \\
& Amotivation & -0.19 & -1.15 & 0.25 & \\
Group 2 - BPN & Autonomy & 0.31 & 2.04 & 0.05 & \\
& Competence & 0.19 & 1.30 & 0.20 & 0.29 \\
& Relation & 0.11 & 0.97 & 0.34 & \\
Group 3 -Affects & Life satisfaction & 0.44 & 4.62 & 0.001 & 0.30 \\
& Positive affects & -0.28 & -2.96 & 0.001 & \\
\hline
\end{tabular}

\section{DISCUSSION}

Starting from the motivation, we observed that mean values of autonomous motivation are slightly higher in the Adapted Sport athletes than in the Regular Sports athletes, the same happens with the levels of controlled motivation, however, it presents statistically significant differences. These results are according with studies by Fernandes (2017), Ferreira (2017), or Gorgatti et al. (2008) who also reported that athletes with disabilities are more likely to engage in behaviours associated with more self-determined motivation than Regular Athletes. Also Skordilis et al. (2003) in his investigation among athletes of Adapted Basketball and Regular Basketball, found more self-determined behaviours in athletes of Adapted Basketball. Regarding gender motivation, our results indicate that male athletes of Adapted Sport have higher levels in autonomous motivation and controlled motivation. In the female gender Regular Sport athletes have higher levels than those of Adapted Sport, in the autonomous motivation and amotivation, and there are no statistically significant differences. These results are according with the study by Ferreira (2017) where Athletes of Adapted Athletics obtained higher mean values in autonomous motivation in both genders, with statistically significant differences, as did Batista et al. (2017) who investigated the same aspect in a study in veteran 
athletes, where they found high levels of intrinsic motivation in both genders. Regarding BPN, our results show approximate means between the variables (autonomy, competence and relation), in relation to Adapted Sport and Regular Sport, with the highest values in Adapted Sport, but we did not obtain statistically significant differences. When compared according to gender we obtained statistically significant differences in the female gender in the need of relation $(p=0.03)$. These are not according with the results of Ferreira (2017), who obtained statistically significant differences for the autonomy and competence variables, with the mean values of Adapted Athletics being higher in all variables of the BPN, but their results of the same variables according to gender are different from ours, as it found statistically significant differences for the three components in the female gender and only in the perception of competence in the male gender. Already Fernandes (2017) obtained differences in the autonomy variable in Adapted Handball, but between genders did not find statistical differences for any of the variables. In life satisfaction, positive and negative affects, the results show higher means in Regular Sport, and when compared to Adapted Sports in relation to life satisfaction and affects, we found statistically significant differences in life satisfaction $(p=0.4)$. Between genders we also found in the life satisfaction statistically significant differences, with $a=0.02$, but only for the male gender. These values go against the literature that tells us that satisfaction of BPN stimulates levels of Life Satisfaction, Fernandes (2017) and Ferreira (2017) found higher mean values for Adapted Sport, but without statistical differences, however, these authors obtained statistically significant differences for positive and negative affects, not according to ours. According to the TSD autonomous motivation, life satisfaction and well-being are correlated with satisfaction of the three basic psychological needs, Batista et al. (2016) found in their study in veteran athletes a positive and significant correlation between autonomic motivation and components of BPN, as well as life satisfaction and positive affects, and the same results were obtained by Fernandes (2017) and Ferreira (2017), but specifically in their adapted sports, and in the study of the second author, the perception of autonomy did not show statistical significance, but the correlation was positive. All these studies agree with TSD and with ours, since the autonomous motivation correlates positively with the perception of autonomy, competence and relation, and with the variables of satisfaction with life and positive affects, since the amotivation presents negative correlation. In Regular Sports there is the same significant positive correlation as in Adapted Sport, and in studies by Fernandes (2017) in handball and Ferreira (2017) in athletics although in this the perception of social relation is not significant. As we have seen in the theoretical basis, there are many studies that discuss the benefits and reasons that lead to sports practice, but in terms of the practical effect it is not enough, so it was difficult to compare our results. Our results were positive that the satisfaction of the psychological needs is a predictor for life satisfaction in Adapted Sport athletes, since R2 $=0.29$, that is, the BPN explain $29 \%$ of the data variance, and with affects explains $30 \%$. In Fernando (2017) BPN accounts for $24 \%$ of the data variance, with life satisfaction as a dependent variable, including Batista, Jiménez-Castuera, Lobato-Muños, Leyton-Román, and AspanoCarrón (2017) obtained a lower value of variance (16\%). It is important to mention a trend in these studies, which is the increase in the value of variance with affects, which in the last two studies mentioned above, obtained $46 \%$ and $31 \%$, respectively.

\section{CONCLUSIONS}

Our theoretical argument states that AS athletes tend to perform behaviours for more intrinsic reasons than RS athletes, which were also observed in this study.

Regarding BPN, we did not find statistically significant differences between AS and RS, and in relation to their mean values, the athletes of AS obtained higher values in all the variables (perception of autonomy, competence and relation). The TSD indicates that there are higher rates of BPN associated with higher rates 
of life satisfaction, so we found statistically significant differences for the life satisfaction variable in AS athletes.

Regarding the comparison between genders, we found statistically significant differences in both genders, namely in the variable of life satisfaction in the male gender, and in the perception of relation in the female gender. Finally, we intend to determine whether any of our variables is predictive of better life satisfaction scores in AS athletes. We conclude that the variables that best explain the variance of the data are BPN $(29 \%)$ and affects, which explain $30 \%$ of life satisfaction in AS athletes.

\section{REFERENCES}

Albuquerque, F. J. B., de Sousa, F. M., \& Martins, C. R. (2010). Validação das escalas de satisfação com a vida e afetos para idosos rurais. Psico, 41(1).

Batista, M., Castuera, R., Lobato, S., Leyton, M., \& Aspano, M. (2017). Diferenças em funcão do género das formas de motivação autodeterminada de atletas veteranos. Ágora para la Educación Física y el Deporte, 1(19), 35-51. https://doi.org/10.24197/aefd.1.2017.35-51

Batista, M., Castuera, R. J., Honório, S., Petrica, J., \& Serrano, J. (2016). Self-determination and life satisfaction: An exploratory study with veteran judo athletes. Revista de Artes Marciales Asiáticas, 11(2s), 90-91. https://doi.org/10.18002/rama.v11i2s.4187

Briki, W. (2016). Motivation toward Physical Exercise and Subjective Wellbeing: The Mediating Role of Trait Self-Control. Frontiers in Psychology, 7(1546), 1-11. https://doi.org/10.3389/fpsyg.2016.01546

Deci, E., \& Ryan, R. (1985). Intrinsic Motivation and Self-Determination in Human Behavior. Plenum Press. https://doi.org/10.1007/978-1-4899-2271-7

Deci, E., \& Ryan, R. (2002). Self-Determination Research: Reflections and Future Directions. In E. L. Deci \& R. M. Ryan (Eds.), Handbook of Self-Determination Research (pp. 431-442): University of Rochester.

Deci, E., \& Ryan, R. (2017). An Approach to human motivation personality. Self-determination theory. org. Retrieved from http://selfdeterminationtheory.org/theoryl

Deci, E., Vallerand, R., Pelletier, L., \& Ryan, R. (1991). Motivation and education: The self-determination $\begin{array}{llll}\text { perspective. } & \text { Educational } & \text { 325-346. }\end{array}$ https://doi.org/10.1080/00461520.1991.9653137

Diener, E., Emmons, R. A., Larsen, R. J., \& Griffin, S. (1985). The satisfaction with life scale. Journal of personality assessment, 49(1), 71-75. https://doi.org/10.1207/s15327752jpa4901_13

Diener, E., Oishi, S., \& Lucas, R. E. (2003). Personality, culture, and subjective well-being: Emotional and cognitive evaluations of life. Annual review of psychology, 54(1), 403-425. https://doi.org/10.1146/annurev.psych.54.101601.145056

Fernandes, M. F. H. (2017). Motivação Autodeterminada e Satisfação com a Vida de Atletas de Desporto Adaptado na Modalidade de Andebol. (Dissertação de Mestrado), Instituto Politécnico de Castelo Branco - Escola Superior de Educação, Castelo Branco.

Ferreira, D. A. M. (2017). Motivação Autodeterminada, Satisfação com a Vida e Integração Social de Atletas de Desporto Adaptado na Modalidade de Atletismo (Dissertação de Mestrado), Escola Superior de Educação do Instituto Politécnico de Castelo Branco, Castelo Branco.

Galinha, I., \& Ribeiro, P. (2005). História e Evolução do Conceito de Bem-Estar Subjetivo. Psicologia, Saúde \& Doenças, 203-214.

Gillet, N., Vallerand, R., \& Paty, B. (2013). Situational Motivational Profiles and Performance with Elite Performers. Journal of Applied Social Psychology, 43, 1200-1210. https://doi.org/10.1111/jasp.12083 
Gorgatti, M., Serassuelo, H., Santos, S., Nascimento, M., Oliveira, S., \& Simões, A. (2008). Tendência competitiva no esporte adaptado. Arquivos Sanny de Pesquisa e Saúde, 18(1), 18-25.

Guimarães, S. É. R., \& Boruchovitch, E. (2004). O estilo motivacional do professor e a motivação intrínseca dos estudantes: uma perspectiva da Teoria da Autodeterminação. Psicologia: Reflexão e Crítica, 17, 143-150. https://doi.org/10.1590/S0102-79722004000200002

Leal, E., Miranda, G. J., \& Carmo, C. R. (2013). Teoria da autodeterminação: uma análise da motivação dos estudantes do curso de ciências contábeis. Revista Contabilidade \& Finanças-USP, 24(62). https://doi.org/10.1590/S1519-70772013000200007

Lonsdale, C., Hodge, K., \& Rose, E. A. (2008). The Behavioral Regulation in Sport Questionnaire (BRSQ): Instrument development and initial validity evidence. Journal of Sport and Exercise Psychology, 30(3), 323-355. https://doi.org/10.1123/jsep.30.3.323

Marques, M. G. (2003). Psicologia do esporte: aspectos em que os atletas acreditam. Canoas.

Monteiro, D., Moutão, J. M., \& Cid, L. (2018). Validation of the Behavioural Regulation in Sport Questionnaire in Portuguese athletes. Revista de Psicologia del Deporte, 27(1), 0145-0150.

Moreno-Murcia, J. A., Marzo, J. C., Martínez-Galindo, C., \& Conte Marín, L. (2011). Validación de la Escala de "Satisfacción de las Necesidades Psicológicas Básicas" y del Cuestionario de la "Regulación Conductual en el Deporte" al contexto español. (Validation of Psychological Need Satisfaction in Exercise Scale and the Behavioural Regulation in Sport Questionnaire to the Spanish context). RICYDE. Revista Internacional de Ciencias del Deporte. https://doi.org/10.5232/ricyde

Pires, A., Cid, L., Borrego, C., Alves, J., \& Silva, C. (2010). Validação preliminar de um questionário para avaliar as necessidades psicológicas básicas em Educação Física. Motricidade, 6(1). https://doi.org/10.6063/motricidade.6(1).157

Ryan, R., \& Deci, E. (2000a). Intrinsic and Extrinsic Motivations: Classic Definitions and New Directions. Contemporary Educational Psychology, 25(1), 54-67. https://doi.org/10.1006/ceps.1999.1020

Ryan, R., \& Deci, E. (2000b). Self-determination theory and the facilitation of intrinsic motivation, social development, and well-being. American psychologist, 55(1), 68. https://doi.org/10.1037/0003$\underline{066 X .55 .1 .68}$

Ryan, R. M., Frederick, C. M., Lepes, D., Rubio, N., \& Sheldon, K. M. (1997). Intrinsic Motivation and Exercise Adherence. International Journal of Sport Psychology, 28(4), 335-354.

Santos, I. M. O. (2015). Pensamentos Automáticos, Esperança e Satisfação com a Vida na Adolescência. (Dissertação de Mestrado), Universidade de Lisboa, Lisboa.

Simões, F., \& Alarcão, M. (2013). Satisfação de necessidades psicológicas básicas em crianças e adolescentes: adaptação e validação da ESNPBR. Psicologia: Reflexão e Crítica, 26, 261-269. https://doi.org/10.1590/S0102-79722013000200006

Siqueira, M. M. M., \& Padovam, V. A. R. (2008). Bases Teóricas de Bem-Estar Subjetivo, Bem-Estar Psicológico e Bem-Estar no Trabalho. Psicologia: Teoria e Pesquisa, 24(2), 201-209. https://doi.org/10.1590/S0102-37722008000200010

Skordilis, E., Gavriilidis, A., Charitou, S., \& Asonitou, K. (2003). Comparison of sport achievement orientation of male professional, amateur, and wheelchair basketball athletes. Perceptual and motor skills, 97(2), 483-490. https://doi.org/10.2466/pms.2003.97.2.483

Vallerand, R. (2007). Intrinsic and Extrinsic Motivation in Sport and Physical Activity: A Review and a Look at the Future. In I. John Wiley \& Sons (Ed.), Handbook of Sport Psychology. New Jersey. https://doi.org/10.1002/9781118270011.ch3

Vallerand, R., Pelletier, L., Blais, M., Brière, N., Senécal, C., \& Vallières, E. (1992). The Academy Motivation Scale: A Measure of Intrinsic, Extrinsic, and Amotivation in Education. Educational and Psychological Measurement, 52, 1003-1017. https://doi.org/10.1177/0013164492052004025 
Vallerand, R., Pelletier, L., Brière, N., Senécal, C., \& Vallieres, E. (1993). On the Assessment of Intrinsic, Extrinsic, and Amotivation in Education: Evidence on the Concurrent and Construct Validity of The Academic Motivation Scale. Educational and Psychological Measurement, 53, 159-172. https://doi.org/10.1177/0013164493053001018

Vallerand, R. J. (2001). A Hierarchical Model of Intrinsic and Extrinsic Motivation in Sport and Exercise. In H. Kinetics (Ed.), Advances in Motivation in Sport and Exercise (pp. 263-320). Champaign: Norway University of Sport Sciense.

Voser, R. d. C., Hernandez, J. A. E., Okubo, J. d. C., \& Junior, M. A. d. S. D. (2017). A motivação para o esporte: um estudo descritivo com atletas profissionais de futebol. Revista Brasileira de Futsal e Futebol, 9(35), 399-405.

Watson, D., Clark, L. A., \& Tellegen, A. (1988). Development and validation of brief measures of positive and negative affect: the PANAS scales. Journal of Personality and Social Psychology, 54(6), 1063. https://doi.org/10.1037/0022-3514.54.6.1063 